\title{
The Fiji Election of 2014: \\ Rights, Representation and Legitimacy in Fiji Politics \\ Stewart Firth
}

Fiji’s 2014 election was its first in eight years, first under the 2013 constitution, and first using a common roll of electors with proportional representation. In the new parliament of 50 seats, the coup leader of 2006, Frank Bainimarama, emerged triumphant. His Fiji First party won 32 seats, with SODELPA, a successor party to earlier indigenous Fijian parties, winning 15 and the National Federation Party three. The election of the new parliament marked the end of Fiji's longest period under a military government since independence. How should we judge the significance of these elections in the context of Fiji's history? Do they represent the breakthrough to democratic stability that so many Fiji citizens have wanted for so long? Or are they just another phase of Fiji's turbulent politics, a democratic pause before another lurch into authoritarian government?

In his message to the nation on Fiji Day, 10 October 2014, the President Ratu Epeli Nailatikau saw recent events as holding great hope for the future. He talked of 1987 as the 'beginning of a cycle of instability, division and hatred - four disruptions to parliamentary rule, a rebellion in the military and in 2000, the detention of our elected representatives for 56 days'. History had now come full circle, he said, as the new members of parliament 'gathered in precisely the same place where the first coup happened 27 years ago', and as the nation finally put this era behind it. ${ }^{1}$

This article explores three recurring themes in the history of Fiji's politics and in the light of the recent election: rights, representation and legitimacy. They have all been contested and the contest over them has been at the heart of that country's political misfortunes.

Rights are moral claims, and the circumstances of Fiji's colonial situation, where an indigenous population kept its land and culture and an immigrant population sought a recognised place in society, made rights a central political issue. The moral claim of the Fijians was based on their prior occupation of the Fiji Islands, stretching back thousands of years, and the moral claim of the Indians was based on their presence, as individuals, in a polity with roots in British liberalism and its philosophy of equal citizenship. Where the

\footnotetext{
${ }^{1} 2014$ Fiji Day Message by H.E. the President, 10 Oct. 2014, http://www.fiji.gov.fj/MediaCenter/Speeches/2014-FIJI-DAY-MESSAGE-BY-H-E-THE-PRESIDENT.aspx
} 
Fijians claimed group rights, the Indians claimed individual rights, while the British seeking to maintain their own predominant position - steered a pragmatic course that mostly ended up on the Fijian side of the argument. The debate did not end with independence in 1970. On the contrary, independence opened the way for a continuing contest over rights in Fiji, one that took the country from democracy to a series of coups - two in 1987 and another in 2000 - that were justified by an appeal to the primacy of the group rights of the original inhabitants of the country.

The debate over rights in colonial Fiji quickly became one about representation, which in the 1920s and 1930s meant representation in the colony's only parliamentary body, the Legislative Council, and which was later to mean representation in the parliament of an independent Fiji. The Fijians, their Europeans and Indians of Muslim faith favoured group representation that would be achieved by means of communal voting rolls, in which the qualification for candidates and voters would be based on ethnic or religious identity; most Indians of Hindu faith (and they were the overwhelming majority) favoured instead the kind of representation that existed in the liberal democracies, where ethnic and religious identity was irrelevant in qualifying candidates to stand and electors to vote, and where all that mattered was status as a British subject.

Legitimacy is the third theme in Fiji's political history. Legitimacy, it has been argued, 'is the quality that transforms naked power into rightful authority; it confers upon an order or command an authoritative or binding character, ensuring that it is obeyed out of duty rather than because of fear'. ${ }^{2}$ Nothing matters more to a government than the acceptance of citizens that it has a right to govern them. That right has different origins, however, in different cultural circumstances. In the pre-colonial chiefly societies of Polynesia and Fiji, leaders established their legitimacy by birthright and by demonstrating their descent from highranking ancestors. They were societies in which genealogies mattered a great deal because they were the keys to power, authority and resources. In the Western liberal tradition to which Fiji was also heir, the legitimacy of a leader is said to derive from successful performance of the legal requirements to achieve leadership, that is, from winning an election conducted under law and according to the constitution. The issue is not one of majorities or voting systems. What matters is adherence to the legal rules whatever they may be. In Fiji's

\footnotetext{
${ }^{2}$ Andrew Heywood, Political Theory: an introduction, $2^{\text {nd }}$ edn, St Martin’s Press, New York, 1999, p. 141.
} 
political history, both kinds of legitimacy, traditional and modern, have been at stake in the fate of governments, and there has been a constant tension between them.

\section{Rights}

On 19 May 2000, the day when armed men took control in Suva and overthrew the government, they erected a sign outside the parliament at Veiuto. It read 'Be Warned Chaudhry: Fiji Indigenous Rights are Paramount in Fiji. We Will Fight to Uphold Them.'3 The phrase 'indigenous rights' became a constant drumbeat in Fiji over the next few months, especially from Speight himself. After parleying with Speight, the army arrested him and hundreds of his followers in the raid on Kalabu Fijian school.

Yet even with Speight out of the way, the mobilising power of 'indigenous rights' remained, as became evident when rebel soldiers mutinied at the Queen Elizabeth Barracks in November 2000 with the aim of doing what Speight had failed to do: establish a Matanitu Vanua [indigenous Fijian government] dominated by Bauan chiefs, with Ratu Jope Seniloli as President and (probably) Adi Samanunu Cakobau as prime minister. The rebellion was put down, Army Commander Commodore Frank Bainimarama avoided assassination, and within a year Fiji had returned to democracy following an election in August 2001. The election, however, returned a government which stood for advancing 'indigenous rights', and which operated in coalition with members of the Conservative Alliance-Matanitu Vanua (CAMV), who were even more committed to that cause than the government. The government of Fiji should be in the hands of Fijians and their chiefs, CAMV declared, and land Fijians had lost should be returned to them. ${ }^{4}$

The outsider who did not know Fiji might have been forgiven for imagining that this was another case of colonial dispossession which had left an indigenous people on the margins of society. The appeal to 'indigenous rights' suggested this was the case, because the discourse of such rights had its origins in the situation of indigenous people in settler societies such as the United States, Canada, Australia and New Zealand, where recompense for past wrongs committed by the settler population has been incorporated into law and become part of a common understanding of national history. The idea of special rights that belong only to the descendants of Fiji's original occupiers is one that continues to exercise a strong hold over

\footnotetext{
3 ‘Armed men take over Fiji parliament’, 19 May 2000, PINA Nius Online.

${ }^{4}$ Anare Tuitoga, 'Tailevu North: five years down the line', in Jon Fraenkel and Stewart Firth, eds., From Election to Coup in Fiji: the 2006 campaign and its aftermath, IPS and Asia Pacific Press, Suva and Canberra, 2007, p. 209.
} 
the imaginations of a minority who see the UN Declaration on the Rights of Indigenous Peoples of 2007 as guaranteeing them a form of self-determination entrenching indigenous dominance. Some Fijians like to think of themselves as members of a small and unique indigenous group whose very survival is at stake in the governing arrangements of their country.

The reality is far different. The British did not dispossess them of their land during the colonial period, 1874 to 1970, in fact quite the opposite. The aim of Fiji's land ordinance of 1880, in the words of the governor Sir Arthur Gordon, was 'to make the alienation of native land as difficult as possible'. ${ }^{5}$ And the ordinance and its successors had that effect over the long term, ensuring that indigenous Fijians would enter the twenty-first century with as much land (more than 83\%) as they had owned a hundred years before. As for participation in government, indigenous Fijians held a dominant position in the governing affairs of their country from independence in 1970, with only a short interregnum between the election of an Indo-Fijian Mahendra Chaudhry, as prime minister in May 1999 and his forcible removal by Speight's nationalists a year later. Thereafter the pattern resumed, with first an elected indigenous prime minister, and then, after the coup of 2006, an unelected one.

In the whole history of independent Fiji, the head of government has been indigenous $97 \%$ of the time, and the military forces, which have played a central role in politics, have remained overwhelmingly indigenous in composition. As the Ghai Constitution Commission put it in 2012, 'The origins of indigenous peoples' rights lie in their status as a minority, subjected to discrimination, politically vulnerable, with their culture under threat. It is not obvious that indigenous people would be entitled to special rights if they were a majority, in control of the state, and owners of $90 \%$ of the land. ${ }^{6}$

The political context of the appeal to 'indigenous rights' in Fiji, then, is different from the expected one. Group rights, it has been pointed out, 'are often articulated as demands for group freedom, but they are also feared as vehicles for group oppression'. ${ }^{7}$ As indigenous Fijian youths rampaged through parts of Tailevu in August 2000, throwing petrol bombs into

\footnotetext{
${ }^{5}$ Colin Newbury Patronage and Politics in the Victorian Empire: the personal governance of Sir Arthur Hamilton Gordon (Lord Stanmore), Cambria Press, Amherst, 2010, p. 103.

${ }^{6}$ The Constitution Commission, Draft Constitution: the Explanatory Report, Suva, 2012, p. 16.

${ }^{7}$ Peter Jones, 'Group rights and group oppression', Journal of Political Philosophy, vol. 7. No. 4, Dec. 1999: 354.
} 
the homes of Indian farmers and threatening them with knives and garden forks, it seemed that such 'rights' in the Fijian setting were little more than excuses for thuggery against people of another race and a means by which unemployed, alienated young men from the villages could revel in a sense of power. ${ }^{8}$

Rights have been contentious in Fiji's modern history. Against the group rights claimed by Fijians the newcomers could counterpose another set. In acquiring Fiji through a Deed of Cession, the British recognised that the original occupiers of the land held rights over it by virtue of prior possession. Cakobau and the other chiefs who agreed to 'cede the possession of and the dominion and sovereignty over the whole of the said islands and over the inhabitants thereof' and who 'requested Her said Majesty to accept such cession' could not have done so, after all, if they were not deemed to have held dominion and sovereignty in the first place. Assuming control of the new British colony, Governor Sir Arthur Gordon told disappointed white settlers that the circumstances of Fiji's Cession prevented it from becoming a white man's colony, and for the next 96 years of colonial administration, the British would see in the Cession a promise of protection owed to the indigenous people of Fiji. The British did not use the term 'indigenous rights' but they acted as if such rights existed, and believed that the Deed of Cession had imposed upon them responsibilities of trusteeship towards the indigenous people of Fiji. In the negotiations over independence in the 1960s their preferred outcome, as Brij Lal writes, was 'Fijian leaders, in control, taking Fiji into independence'.

The Deed of Cession came to assume symbolic significance for indigenous Fijians, too. Many saw it as a charter guaranteeing Fijian paramountcy. When Sitiveni Rabuka seized power in 1987 he revived the old claim, cherished by Fijian nationalists, that independence should have been a literal reversal of the Deed of Cession, returning the country not to all the people of Fiji but to the Fijians alone: 'The Fijians felt that their land should have been handed back to the chiefs who, in good faith, ceded the islands to Queen Victoria for her to protect. So far as the Fijian people are concerned, this is the missing link - the handing back of their beloved country to them, and not to the strangers who, in the course of time, would decide the Fijians' fate in their own country'. This interpretation of the Deed of Cession sustained the hopes of the nationalists for decades, and appeared again in the rhetoric of

\footnotetext{
8 'Nightmare continues for Indians in rural Fiji', fijilive, 2 Aug. 2000.

${ }^{9}$ Brij V Lal, ed., British Documents on the End of Empire, Series B, Volume 10: Fiji, London, 2006, p. lxxiv. 
2000, but had no historical substance. As Ratu William Toganivalu said in 1970, 'there was nothing in the Deed of Cession to say that when England was to hand over Fiji that it was to hand it over holus-bolus to the Fijian people alone'. ${ }^{10}$

What about the people who had migrated in large numbers from the Indian sub-continent to work on the plantations of Fiji? What rights did they have as settlers and the descendants of settlers born in a new land? This was the question that exercised the leaders of the Indian community from the 1920s onwards, and their answer was to appeal to the rights of British subjects. The Indian leaders of that period were influenced not only by the movement for independence in India itself, but also by the fate of Indians in other parts of the British Empire, which was seen as responsible for their personal humiliation and that of a great civilization.

\section{Representation}

Indian leaders such as Vishnu Deo and S. B. Patel took their lead from the Indian National Congress, and saw local events as part of a wider struggle taking place in countries as far away as Kenya, where, as in Fiji, Europeans were resisting Indian claims to equal treatment. The question of the rights of Indians in British colonies, moreover, immediately raised the issue of their political representation. Hence the attachment of the Indian leaders to the principle of the common voting roll, drawn up irrespective of race, in elections to the Legislative Council. In their view, British subjects in Fiji should all be on the same voting roll, not divided into separate rolls according to racial identity. And that is why, when election of Indians to the Legislative Council was introduced in 1929, the three who were elected decided upon a plan of action even before its first meeting. They would move a motion proclaiming that political rights along racial lines were unacceptable, demand that Indians be given a common franchise with other British subjects in Fiji, enumerate Indian grievances in detail, and then resign.

When they did so, they were heroes in India - Gandhi himself congratulated them for their patriotism - but suspect in Fiji. Governor Sir Murchison Fletcher saw Fiji Indian politicians

\footnotetext{
${ }^{10}$ Quoted in William E.H. Tagupa, 'The Unanticipated Republic of Fiji: Deed of Cession as the Constitutional Basis of Legitimacy', in William Renwick, ed., Sovereignty and Indigenous Rights: the Treaty of Waitangi in International Contexts, Victoria University Press, Wellington, 1991, pp. 142, 145.
} 
of this kind as 'the uninformed tool of an extraneous organization which is dangerously seeking opportunity to use the Colony for the purposes of its world-wide attack upon the British Raj', ${ }^{11}$ and their dramatic resignation merely confirmed the Fiji government's view that communal voting should remain. Fletcher explained his reasoning to the Legislative Council in 1933:

There is an essential difference between this Colony and a country such as England or Australia that Fiji lacks the homogeneity of race and racial sentiment which is ordinarily found elsewhere [sic]. In Fiji there are three principal groups, European, Fijian and Indian, each having an independence of outlook which it will not willingly surrender or merge, and the Europeans and Fijians have emphatically refused to subordinate their separate interests to that Indian preponderance which would in their belief eventuate, if the Indian request for a common roll for the Legislative Council were granted. $^{12}$

In the 1936 constitutional reform, which remained in essence until 1963, the three elected Indian members of the Legislative Council continued to be chosen by voters in communal constituencies. Resignation and boycotts, meantime, became characteristic of the way Fiji Indians interacted with the emerging representative institutions of Fiji in the years before independence. In a deeply divided society, political styles diverged. Where Fiji Indian leaders were blunt and outspoken in their demands the indigenous Fijian leaders were deft and polite, concealing as much as they revealed, yet quietly determined to maintain their position.

In some ways Fijian society remained static until well after the mid-twentieth century, with commoners subjected to a chiefly order that had the full backing of the British colonial administration, though we should remember that Fijians were already beginning to live away from their villages. The chiefs were the principal beneficiaries of the British presence. They stood at the apex of an indigenous hierarchy, and their powers over commoners were enshrined in law. Commoner Fijians engaged in repeated acts of resistance against the government in the early decades of the colonial period, and were never as satisfied with their subordinate position in an aristocratic society as the British and the chiefs liked to think. As

\footnotetext{
${ }^{11}$ Quoted in K.L. Gillion The Fiji Indians: Challenge to European Dominance 1920-1946, ANU Press, 1977, pp. 140-41.

${ }^{12}$ Address by His Excellency the Governor, $13^{\text {th }}$ October, 1933, CP No. 30, Journal of the Legislative Council (Fiji), 1933.
} 
Robert Nicole has pointed out, the accepted version of Fiji's history - the one found in landmarks, celebrations and school texts - elevates Ratu Sir Lala Sukuna to the status of a national hero, while little is ever heard of Apolosi Nawai, who captured the imagination of thousands of commoner Fijians in the early decades of the $20^{\text {th }}$ century with his vision of a Viti Company that would bypass the stranglehold held by Europeans on the copra trade. ${ }^{13}$ Commoners never completely reconciled themselves to chiefly dominance. Writing of Deuba village in the mid-1940s, William Geddes said people resented having to leave their own gardens to undertake communal work for the roko, the women complained about the work involved in preparing mats and food for chiefly ceremonies; and the preference shown to chiefs in being given government and army jobs was a source of widespread grievance. ${ }^{14}$ Yet at the same time commoners invariably showed deference towards chiefs in their presence. 'Ambivalence' is the word that best captures this characteristically Fijian attitude, which was a mixture of resentment and respect.

To be 'Fijian' was to assert a strong and distinctive identity that justified claims to paramountcy in a divided society and gave access to resources, above all, land. But to be 'Fijian', despite the unifying effect of this identity on the entire indigenous population, was not to be part of an undifferentiated group of people who all thought the same way. As many have pointed out, the idea of a single iTaukei identity papered over deep divisions in the Fijian community, and delivered power to the chiefly class who spoke in the name of all their compatriots. The assumption behind the representation of communities that inspired the idea of communal constituencies was that cultural identity came first and individual interests second, and that chiefs were in the best position to represent all Fijians.

The communalism of village life was supposed to be reflected in the communalism of Fijian political representation, and until 1963 Fijians did not vote at all. Instead, they were represented in the Legislative Council by five nominees of the governor acting on the advice of the Great Council of Chiefs. For Fiji’s greatest chief, Ratu Sir Lala Sukuna, representation of this kind was the only kind compatible with Fijian tradition. He considered democracy unFijian and thought Fijians would never understand a system based on the counting of heads. Sukuna died in 1958, and by then the forces of modernity and individualism were rendering

\footnotetext{
1313 Robert Nicole, Disturbing History: Resistance in Early Colonial Fiji, University of Hawai i Press, Honolulu, 2011, p. 97.

${ }^{14}$ William R Geddes, Deuba: A Study of a Fijian Village, IPS Reprint Series, Suva, 2000, p. 88.
} 
outmoded his vision of a people bound by obedience to chiefs and unquestioning attachment to the vanua.

Representation was the key to power, and was therefore a central issue in the negotiations over independence that gathered pace from 1965. In his final dispatch before independence the last governor, Sir Robert Foster, concluded that a 'calm search for a just solution to the problem of representation proved virtually impossible: feelings ran too deep., ${ }^{15}$ On the Indian side A D Patel stuck to his advocacy of common roll as a matter of principle. At the Marlborough House conference in 1965 the Indian group led by Patel submitted that communal role stood for divided loyalties, would magnify communal differences and would stand in the way of parliamentary democracy; in short, it should be abolished. The only solution for Fiji was common roll, as he told voters in the Sigatoka Valley during the 1966 election campaign: 'We have to bring everyone together and the only way to do that is by means of common roll. We can no longer think along the lines that we are Fijians, we are Indians, we are Europeans or Chinese. We must think of ourselves as citizens of Fiji, that we are nationals of Fiji.' 16

The Fijians led by Ratu Mara held precisely the opposite view, for 'the great Fijian fear was that a Common Roll Legislature would change the law on land and deprive them of their security of ownership', as he told Trafford Smith of the Commonwealth Office. The Fijians were not convinced 'that written safeguards against such action would be adequate' ${ }^{17}$ Fijian fears on this score were heightened by the demographic facts. By the mid-1960s the Indian population was $51 \%$ of the country's population and the Fijian $41 \%$, suggesting that any voting system based on numbers alone would deliver a permanent majority to the Indians. A supporting assumption - that most people would vote for candidates of their own race seemed borne out by the victories of the Federation Party in the by-elections of 1968, and likely anyway in the social circumstances of Fiji. Whatever the democratic merits of A D Patel's argument, and they were considerable, the Fijians saw common roll as a road to disaster and would not countenance it as the basis for entering independence. In this insistence they had the support of the British government, whose policy after the 1965

\footnotetext{
15 'Fiji: final despatch before independence': despatch from Sir R Foster to Sir A Douglas-Home 8 Oct 1970, in Lal, ed., British Documents on the End of Empire, Series B, Volume 10: Fiji, p. 517.

${ }^{16}$ Brij Lal, ed. A Vision for Change: Speeches and Writings of AD Patel, 1929-1969, ANU E Press, 2011 , p. 94.

17 “'Interviews with political leaders in Fiji': note by Trafford Smith after his recent visit', in Lal, ed., British Documents on the End of Empire, Series B, Volume 10: Fiji, p. 207.
} 
conference was to recognize 'that election on a straight common roll basis was not practicable for Fiji until a greater degree of integration of the Co [colony's] communities had been achieved', the position that remained when the British Cabinet accepted independence for Fiji in $1970 .^{18}$

The death of A D Patel in 1969 removed Fiji's most able proponent of common roll from the Indian political leadership. According to Governor Foster, Patel's successor Siddiq Koya was 'a plump little lawyer, full of intrigue and calculation, who wears the mask of amiable geniality which occasionally slips to reveal the hatchet man beneath'. A 'wheeler-dealer if ever there was one', wrote Foster, 'he probably has no basic principles'. ${ }^{19}$ The consequence was a change in the political atmosphere, with Koya more willing to compromise with Mara in the interest of achieving independence, and making the key concession that deferred consideration of common roll for five years, when it was to be the subject of a Royal Commission. Once that time came and the Street Commission recommended 25 open seats to operate alongside communal seats, Mara was able to dismiss its proposals as a threat to the peace of the country.

Race was institutionalized in the post-independence politics of Fiji, which entered independence in 1970 with a constitution that preserved communal representation and indigenous rights. In the lower house all 52 seats were reserved for one racial group or another, Fijian, Indian and 'General'. 25 were filled by a system of election called 'crossvoting', which specified the race of the candidate while allowing everyone to vote; and 27 were filled by communal voting, which specified the race of both candidates and voters.

Democracy lasted for as long as the Alliance Party won elections, but in 1987 the elections were won by a coalition consisting of the National Federation Party and the new Fiji Labour Party, with a Fijian prime minister, Timoci Bavadra, and a cabinet consisting of both indigenous Fijians and Indo-Fijians. That was too much for Rabuka, who staged Fiji's first coup in order to overthrow what he called an 'Indian-dominated' government, plunging his country into the first of its periods of military government. Later that year he issued a decree requiring 'that a new Constitution replace the Constitution under which [the people of Fiji]

\footnotetext{
18 'Fiji independence': memorandum by Mr Stewart for Cabinet Defence and Oversea Policy Committee, 8 Jan 1970, in Lal, ed., British Documents on the End of Empire, Series B, Volume 10: Fiji, p. 435.

19 'Fiji: final despatch before independence': despatch from Sir R Foster to Sir A Douglas-Home, 8 Oct 1970, Lal, ed., British Documents on the End of Empire, Series B, Volume 10: Fiji, p. 514.
} 
attained independence on $10^{\text {th }}$ October $1970,{ }^{20}$ Fiji's second constitution, promulgated in 1990, abolished cross-voting and strengthened communal voting. The paramountcy of the indigenous Fijians was to be maintained in the crudest of ways, by giving 37 of Parliament's 70 seats to Fijians, with $48 \%$ of the population and only 27 to Indo-Fijians, whose numbers had dropped but still amounted to $46 \%$. By various other stratagems, the votes of urban Fijians counted for much less than those from rural areas. Justifying a constitution extraordinarily skewed to the advantage of Fijians, President Ratu Sir Penaia Ganilau called it 'a continuation, and enlargement, of an idea which has become an established part of our power-sharing arrangements', ${ }^{21}$ an argument that failed to convince the Indo-Fijian community, for whom it was both an insult and an imposition. Internationally, too, Fiji's 1990 constitution was widely condemned.

The 1990 constitution provided for its own review within seven years. Well before then, Rabuka, now the elected prime minister, appointed a constitution review commission. He was driven by considerations of political survival. Fiji had not done well since the 1987 coup. Almost 66,000 people left Fiji permanently between 1987 and 1994, most of them IndoFijian, and in the process they deprived the country of some of its best and most skilled citizens, leaving behind an economy in decline. By the mid-1990s politicians on all sides recognized that Fiji needed a constitution that would restore its place in the international community and revive the country's economic fortunes. In the commission the Fiji-born academic Brij Lal sat alongside the former New Zealand Governor General Sir Paul Reeves and a former minister and speaker of the Fiji House of Representatives Tomasi Vakatora. They confronted in the most tangible way the urgency of finding a constitutional solution that would take account of 'the rights, interests and concerns of all ethnic groups'.22

The outcome of their deliberations was the 1997 constitution. The Fiji parliament accepted much of what the commissioners proposed but, on the key issue of representation, reversed their recommendation. The commissioners suggested that, in a parliament of 71 seats, there should be 46 open seats and 25 communal; the government decided upon 46 communal seats and 25 open. The difference was significant. It meant that communal representation remained

\footnotetext{
${ }^{20}$ Declaration - Republic of Fiji Decree 1987. No. 8, 1 (a), reproduced in Brij V Lal, Power and Prejudice: the Making of the Fiji Crisis, New Zealand Institute of International Affairs, Wellington, 1988, opposite p. 118.

${ }^{21}$ Brij V Lal, Broken Waves: A History of the Fiji Islands in the Twentieth Century, University of Hawaii Press, Honolulu, 1992, p. 327.

${ }^{22}$ Brij V Lal Islands of Turmoil: elections and politics in Fiji, Asia Pacific Press, 2006, p. 129.
} 
the central and defining characteristic of Fiji's electoral system with an experiment in common roll now added, rather than the opposite. The 1997 constitution also provided for something else the Commission had not recommended - power sharing - but it was only in 2006, and then only for a few months, that a Fiji government included opposition members in its cabinet as the power sharing provision required.

In any case, the military commander Frank Bainimarama soon led his troops to a coup which replaced representation with intervention. ${ }^{23}$ The attempts of the representative leaders of Fiji to rein in the military proved futile, and the government of Laisenia Qarase, elected in 2001 and again in 2006, became ineffectual. Talk of the government disciplining the military commander for his open opposition never led to action, and an emboldened commander finally acted on the logic of his situation. He despised the elected government, he had the guns, so he overthrew it. Bainimarama depicted his 2006 coup as a courageous act of constitutionalism aimed to saving the people of Fiji from destruction at the hands of the elected government. Extraordinarily, he claimed to have done nothing illegal or unconstitutional: 'The Republic of Fiji Military Force could have carried out unconstitutional and illegal activities, but had not done so and will not do so. It believes in the rule of law and shall adhere to the Constitution. It not only adheres to the rule of law and Constitution, but more importantly believes in adherence to the spirit of the law and the Constitution' ${ }^{24}$

Bainimarama abandoned this pretence of legality within three years. In April 2009, acting through a senile President who was unaware of what was happening, he abrogated the constitution, declared a state of emergency, deported foreign journalists, censored the media, brought the legal profession under direct government control and sacked, among others, the ombudsman, supervisor of elections, auditor-general, director of public prosecutions, the governor of the Reserve Bank and the commissioner of police. In the process Bainimarama created a new and unprecedented political atmosphere, in which criticism of the government became treasonous. Together with his Attorney-General Aiyaz Sayed-Khaiyum, Bainimarama governed Fiji under a state of emergency for the next three years, as they issued

\footnotetext{
${ }^{23}$ Jon Fraenkel. Stewart Firth and Brij V Lal, eds., The 2006 Military Takeover in Fiji: a Coup to end All Coups? ANU E Press, 2009.

24 ‘Army chief defends take over’, Fijilive, 5 Dec. 2006. 
a succession of decrees that were the antithesis of legislation in a system of parliamentary representation.

Yet the problem of representation in a future Fiji remained. Like all military rulers, Bainimarama discovered he could not rule by decree for ever. He began a cautious liberalisation in early 2012, and appointed a constitution review commission, led by constitutional expert Yash Ghai. The commission was instructed to break with Fiji's long history of race-based, single-member constituency electoral systems. Any new constitution would have to include provisions for one person, one vote, one value; the elimination of ethnic voting; and proportional representation. As it happened, the Bainimarama government spurned Ghai's draft constitution and came up with one of its own, the 2013 one that is now the law of Fiji. The new constitution - Fiji's fourth since independence - stipulates that the 50 members of parliament will be elected by proportional representation with the proviso that 'a political party or an independent candidate shall not qualify for any seat in Parliament' unless they receive at least at least $5 \%$ of the votes. ${ }^{25}$

In the 2014 elections this system delivered a clear victory for Bainimarama and his FijiFirst Party, which gained 59.2\% of the vote, with SODELPA (Social Democratic Liberal Party) winning 28.2\% and the NFP (National Federation Party) 5.5\%. The independents and other parties, including the once-mighty Fiji Labour Party, failed to clear the 5\% hurdle and are not in the new parliament.

\section{Legitimacy}

As much as it is a story of rights and representation, the journey taken by Fiji since independence is one in which legitimacy plays a key part.

High chiefly rank remained a qualification for important government or military office in Fiji throughout the British colonial period and is only now beginning to lose its significance. The brilliantly talented Fijian commoner Rusiate Nayacakalou was thought to be almost a genius by his headmaster at Suva Methodist Boys' School in the 1940s, but the Great Council of Chiefs would not award him a scholarship to study in New Zealand because he was not of chiefly rank. Other commoners suffered similar fates.

${ }^{25}$ Constitution of Fiji, 2013, section 53 (3). 
A bright boy of chiefly rank, on the other hand, found all doors were open. Such was the case for Ratu Mara, who inherited the title of Tui Nayau from his father and married one of Fiji's highest ranking chiefs, Adi Lala Mara. As the paramount chiefly head of the Burebasaga Confederacy, she held the title of Roko Tui Dreketi, and as Mara’s wife was Radi Ni Nayau. Identified early as a promising future leader, Mara was educated at Otago University, Oxford and the London School of Economics, and groomed for leadership by both his chiefly peers and British colonial officials. Sir Robert Foster, the last governor, found Mara a dignified aristocrat who inspired 'awe rather than confidence' and was given to 'a dictatorial arrogance which does not make him easy to work with', a man who 'believes (without being antiIndian) that Fijian paramountcy is proper and natural'. ${ }^{26}$ These characteristics were not always seen as negatives by the British, though, who thought he was the best person to take Fiji into independence. Of high rank by birth, Ratu Mara also possessed a modern kind of legitimacy, as the country's chief minister under self-government in the 1960s and its first prime minister, elected according to law under the constitution of 1970. The key point in his favour, as far as the British were concerned, was that Mara embodied both forms of legitimacy, and both would assist in conferring upon his commands, and those of his government, 'an authoritative or binding character'. He would, they hoped, bring stability to the country. And for a while he did.

Mara lasted longest as a political leader, both as prime minister and president, because he combined traditional and modern forms of legitimacy, but his successors encountered endless difficulties. Ideas of indigenous rights and Fijian paramountcy, after all, suggested the existence of claims to authority that were prior to any that might arise from being elected. From the point of view of group rights, the result of an election was only one consideration in determining who the government should be; another might override it in the service of a greater interest, as both Rabuka and Speight claimed when they took over parliament by force and declared themselves to be in charge. In effect, they declared the elected governments of Bavadra and Chaudhry illegitimate because, in their view, they failed to meet the test of protecting indigenous rights.

Bainimarama’s 2006 coup was different. By his actions he was declaring an elected government illegitimate, but on different grounds, namely that it was corrupt and that a thorough clean-up was needed for the sake of the country. This approach extended the

\footnotetext{
26 'Fiji: final despatch before independence': despatch from Sir R Foster to Sir A Douglas-Home, 8 Oct 1970, Lal, ed., British Documents on the End of Empire, Series B, Volume 10: Fiji, p. 514.
} 
justification for armed takeovers beyond the issue of rights into the terrain of government performance: if a government was not performing well, it deserved to be overthrown by force. And, as happened in 2009, if the courts were thought to be wrong in reaching a judgement, they should be ignored and the constitution abrogated.

For the moment stability has come to Fiji. Has Bainimarama cut through the Gordian knot of rights, representation and legitimacy and finally set Fiji on a genuinely democratic path? The appeal of indigenous rights, revived by SODELPA in the election, seems weaker than ever, especially to younger Fijians. Common roll has triumphed at last, but more than forty years after independence and in a political atmosphere that, at least in the person of Bainimarama, lacks the respect for representative institutions that once characterised Fiji's leaders and their debate over the country's electoral arrangements. The final release of the Auditor-General's reports has revealed over-spending by the Fiji military forces in the years following the 2006 coup. These shortfalls are unlikely to be made good by the new government, which is not disposed to admitting mistakes. ${ }^{27}$ As for legitimacy, Bainimarama is inclined to see parliament as the instrument of his continued domination of Fiji's affairs, useful but in the end dispensable.

When Ratu Mara died in 2004, a state funeral service was held in Albert Park before a gun carriage bore his body through the streets of Suva on its way to the wharf, where it travelled by sea to his birthplace in the Lau Islands. As the gun carriage passed, heads were bowed and a hush fell over the entire crowd, children as much as adults, in mute testimony to the respect he inspired. Looking back, that day seems to have been a turning-point in the history of Fiji, more so than we realised at the time. Within less than three years, the government would be in the hands of a military leader who had little time for the old Fiji of aristocratic privilege, the Great Council of Chiefs, and the Methodist Church, and who would deal telling blows to each of them during his years as self-appointed prime minister.

In a formal sense the Fiji of Mara and the chiefly order has gone forever. Yet a new kind of chief has arisen in the person of Frank Bainimarama, whose election campaign made much of his personal achievements as Fiji's leader. His legitimacy is modern and charismatic rather than traditional, and his personal vote of 202,459 votes - far more than that for any other

27 'Fiji 2007 audit shows military overspend', Pacific Beat, Radio Australia, 22 Oct. 2014. 
candidate - shows his cult of the leader has widespread support. Bainimarama is the foundation stone of the current political order and has rendered himself indispensable to Fiji's current stability. The corollary is that Fiji’s stability may not endure after he leaves the scene. 